\title{
Levels of Fe and Zn in Staple Cereals: Micronutrient Deficiency Implications in Rural Northeast Nigeria
}

\author{
Umar Musa $^{1}$, Stephen S. Hati ${ }^{2, *}$, Abdullahi Mustapha ${ }^{1}$ \\ ${ }^{1}$ Department of Pharmaceutical and Medicinal Chemistry, ABU Zaria, Nigeria \\ ${ }^{2}$ Department of Chemistry, IBB University, Lapai Nigeria
}

\begin{abstract}
Maize, millet, rice and sorghum are staple cereals and major source of micronutrients for rural dwellers of Northeast Nigeria. These cereals were randomly sampled form the open markets and investigated for the levels of Iron (Fe) and $\mathrm{Zinc}(\mathrm{Zn})$ with a view to provide supportive monitoring information on possible dietary deficiency implications. The standard calibration method of flame atomic absorption spectrometry was used for the determination of $\mathrm{Fe}$ and $\mathrm{Zn}$ in the cereals. The results of the analysis show average Fe concentrations in cereals: Millet $(10.28 \pm 2.38 \mu \mathrm{g} / \mathrm{g})$, Maize $(5.26 \pm$ $1.41 \mu \mathrm{g} / \mathrm{g})$, Sorghum $(11.03 \pm 5.32 \mu \mathrm{g} / \mathrm{g})$ and Rice $(6.67 \pm 5.94 \mu \mathrm{g} / \mathrm{g})$, and average $\mathrm{Zn}$ concentrations in cereals, Millet $(5.89 \pm 0.88 \mu \mathrm{g} / \mathrm{g})$, Maize $(3.92 \pm 0.91 \mu \mathrm{g} / \mathrm{g})$, Sorghum $(3.84 \pm 0.92 \mu \mathrm{g} / \mathrm{g})$, Rice $(1.80 \pm 0.32 \mu \mathrm{g} / \mathrm{g})$. This study revealed low levels of $\mathrm{Zn}$ and $\mathrm{Fe}$ in the cereal grains from the study areas, an observation that might be a risk factor for micronutrient malnutrition in the populations of rural dwellers of this region that depend so much on these cereals in their diets. Thus although exposure effects could be additive for $\mathrm{Fe}$ where similar foods are eaten, the $\mathrm{Zn}$ and Fe contents of the cereal grains may also be hampered from full absorption in the body due to lack of aiding diet components and certain cultural practices.
\end{abstract}

Keywords Cereal grains, Essential nutrients, human health, rural dwellers

\section{Introduction}

Micronutrient malnutrition is a major global health concern because its deficiency in the body is linked with ill health and diseases. The concern is more crucial on developing countries, especially in children, given that the statistics of malnutrition in these countries are high. More than half of the total population in developing countries are reported to be affected by micronutrient deficiency and therefore more susceptible to infections and impairment of physical and psycho-intellectual development[1]. In subSaharan countries, $28 \%$ of the children under the age of 5 years are underweight, $38 \%$ are stunted and, $9 \%$ wasted. Stunting which is defined as low height for age is considered as an indicator of chronic malnutrition whereas wasting which is low weight for height is a measure of acute malnutrition[2]. In Northern Nigeria about $38.5 \%$ of the children under five are reported to be stunted, with $9.3 \%$ incidence of wasting. This indicates chronic malnutrition among this age group[1].

Micronutrient malnutrition normally occurs when the essential elements are not sufficient to fulfil the need of the body to develop and function normally. Iron (Fe), Zinc ( $\mathrm{Zn})$ and Iodine (I) deficiencies are the most occurring nutritional

* Corresponding author:

stevehati@yahoo.com (Stephen S. Hati)

Published online at http://journal.sapub.org/fph

Copyright (C 2012 Scientific \& Academic Publishing. All Rights Reserved deficiencies in the world although the threat from the deficiency of Iodine has been reduced through the Iodine fortification of table salt (Iodated salt) $[3,4]$.

Studies have also shown persistent Fe deficiency anaemia and common stunted growth among school children[5,6]. Fe deficiency affects the physical work capabilities and cognitive development of children[7], whilst deficiency of $\mathrm{Zn}$ increases weight loss, growth failure and immunity problem[8].

Majority of rural dwellers in northeast Nigeria are not likely to have access to dietary supplements for Fe and Zn. Apart from minor intake of fruits and vegetables, the major source of micronutrients are in the staple cereals (maize, millet, rice and sorghum), which form the major ingredient of most diet in this region. This study attempts to examine the levels of $\mathrm{Fe}$ and $\mathrm{Zn}$ in these staple cereals cultivated in two states of northeast Nigeria with a view to provide supportive monitoring information.

\section{Materials and Method}

\subsection{Samples and Sampling}

Samples of four staple cereal grains (maize, millet, rice and sorghum) that are locally cultivated in Borno and Yobe States, Northeast Nigeria were sampled according to standard procedure[9] and representative composite samples were obtained from bulk purchases $(2 \times 5 \mathrm{~kg}$, for each cereal grain). Retail markets from which purchases were made 
comprise 3 clusters of estimated 12 local government areas (LGA) of Borno State. Samples were collected in linear polyethylene containers and sampling took place during the period June 2008 and December 2009.

\subsection{Sample Preparation}

Composite samples $(1 \mathrm{~kg}$ each) were drawn from the thoroughly mixed composites and ground using mortar and pestle. The dry ashing method[10,11] was employed in this study. The ground samples (10 g each) were placed in porcelain crucibles and few drops of concentrated nitric acid was added to support the ashing. This was further carried out in a furnace at $450^{\circ} \mathrm{C}$ for four hours with a temperature increase of $50^{\circ} \mathrm{C}$ per hour to avoid self-ignition in the samples. Thereafter, the ash was moistened with few drops of deionised water, dried and re-ashed. This process was repeated until a carbon-free ash (white or slightly coloured with no charred particles) was obtained. The ash was left to cool and was dissolved in $4 \mathrm{~mL}$ of $20 \% \mathrm{HCl}$. The ash suspension was filtered through a $0.45 \mu \mathrm{m}$ membrane filter into a $50-\mathrm{mL}$ volumetric flask and the filtrate made up to volume with deionised water.

\subsection{Determination of $\mathrm{Fe}$ and $\mathrm{Zn}$ in Cereals}

The standard method[10] of Flame Atomic Absorption spectrophotometry (FAAS) was used in the determination of $\mathrm{Fe}$ and $\mathrm{Zn}$ in cereals. Shimadzu AA-6800 outfitted with ASC-6100 auto sampler and air-acetylene atomization gas mixture system was used. Standard solutions of $\mathrm{Fe}$ and $\mathrm{Zn}$ were separately prepared from their respective concentration of $1000 \mathrm{mg} / \mathrm{ml}$ stock solutions (Shimadzu, GmBH), from which further serial dilutions $(0.1-4 \mathrm{mg} / \mathrm{ml})$ were made to cover the optimum absorbance range for the standard calibration curve. For the determination, two solutions were prepared for each sample. Reagent blank determinations were used to correct the instrument readings[11]. The average concentration of 20 blanks was deducted from the recorded results before the level of each metal was calculated. Sample runs were conducted in triplicates.

\subsection{Statistical Analysis}

Statistical analysis was performed using Analyse-it ${ }^{\circledR}$ statistical software for Microsoft Excel 2007. Test for significance was carried out at $95 \%$ confidence interval and tests was considered significant at $\mathrm{P}<0.05[12]$.

\section{Results}

Figure1 shows the results of $\mathrm{Fe}$ concentrations in the various cereal grains at the different locations. The results revealed that with the exception of millet from Maiduguri, the $\mathrm{Fe}$ content was generally higher in the other cereals (i.e. maize, sorghum and rice) from Monguno. The cereals from Gashua in Yobe state showed, in most cases, moderate Fe concentrations compared to the other two locations. The sorghum from Monguno showed the highest concentration of Fe $(17.89 \pm 0.67 \mu \mathrm{g} / \mathrm{g})$ while the least Fe level $(2.49 \pm 0.17$ $\mu \mathrm{g} / \mathrm{g}$ ) was recorded in rice samples from Maiduguri. This pair of results obviously revealed an extremely wide variation in Fe content across locations. The Box-Whiskers plot (Figure 2) shows the concentration spread of $\mathrm{Fe}$ in the cereals. Due to the non-normal distribution the median concentration is represented on the plot. Rice $(2.84 \mu \mathrm{g} / \mathrm{g})$ and Sorghum $(9.17 \mu \mathrm{g} / \mathrm{g})$ presented the widest variations. On the whole, an average $\mathrm{Fe}$ concentrations in cereals Millet $(10.28 \pm 2.38$ $\mu \mathrm{g} / \mathrm{g})$, Maize $(5.26 \pm 1.41 \mu \mathrm{g} / \mathrm{g})$, Sorghum $(11.03 \pm 5.32 \mu \mathrm{g} / \mathrm{g})$ and Rice $(6.67 \pm 5.94 \mu \mathrm{g} / \mathrm{g})$ was recorded in this study.

Analyses of variance (ANOVA) showed that the variations of Fe concentrations between locations were, with the exception of Maiduguri and Gashua, significant $(\mathrm{p}<0.05)$. On the basis of cereal type, the variations in Fe concentrations were significant $(p<0.05)$ for all pair wise, with the exception of sorghum and millet.

Pearson correlation coefficient (r) values (Figure 3) for Fe concentrations between cereals showed that millet and maize $(\mathrm{r}=0.76)$, maize and rice $(\mathrm{r}=0.70)$ and sorghum and rice $(\mathrm{r}=$ $0.98)$ were higher than the high positive limit $(r=0.65)$ set for this study. Conversely, millet and sorghum showed the lowest correlation $(\mathrm{r}=0.06)$ for $\mathrm{Fe}$ concentrations.

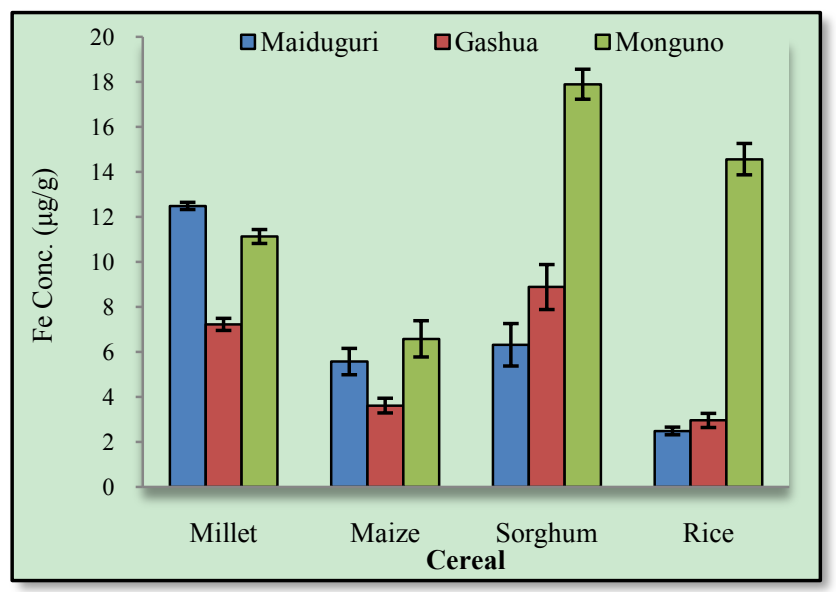

Figure 1. Fe concentrations at the different locations

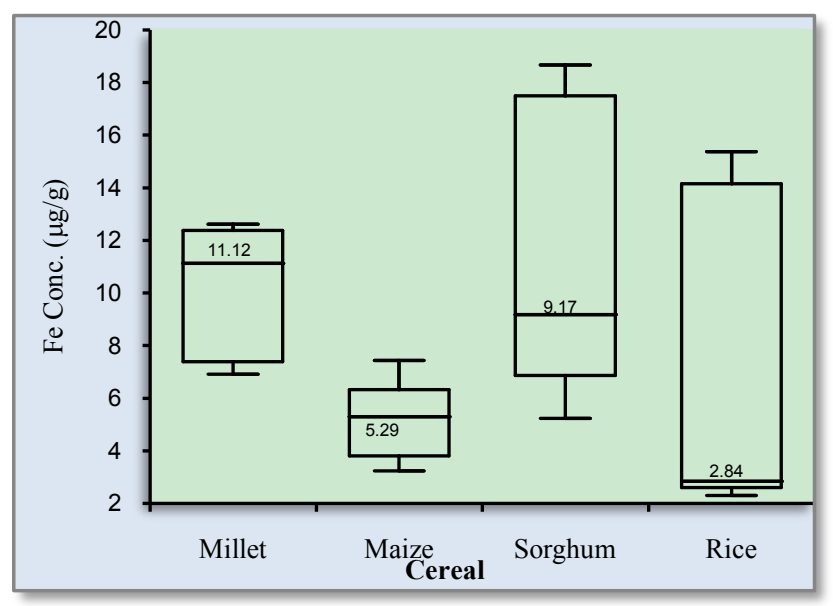

Figure 2. Box-Whisker plot of Fe concentration spread in cereals

Figure 4 shows the results of $\mathrm{Zn}$ concentration in the cereals at the different locations. The results showed that 
samples of millet obtained from Gashua, Yobe State contained the highest concentration of $\mathrm{Zn}(6.41 \pm 0.08 \mu \mathrm{g} / \mathrm{g})$, while the least $(1.50 \pm 0.19 \mu \mathrm{g} / \mathrm{g})$ was in rice samples from Maiduguri, Borno State. Similar to Fe concentration, wide variation in $\mathrm{Zn}$ content across locations was also observed. Also, the Box-Whiskers plot (Figure 5) shows the varying concentration spread of $\mathrm{Zn}$ in the cereals. The median concentration of the distribution is represented on the plot. Rice $(2.84 \mu \mathrm{g} / \mathrm{g})$ and Sorghum $(9.17 \mu \mathrm{g} / \mathrm{g})$ presented the widest variations and non-normal spread (Shapiro-Wilk's test, $\mathrm{P}<0.05$ ).

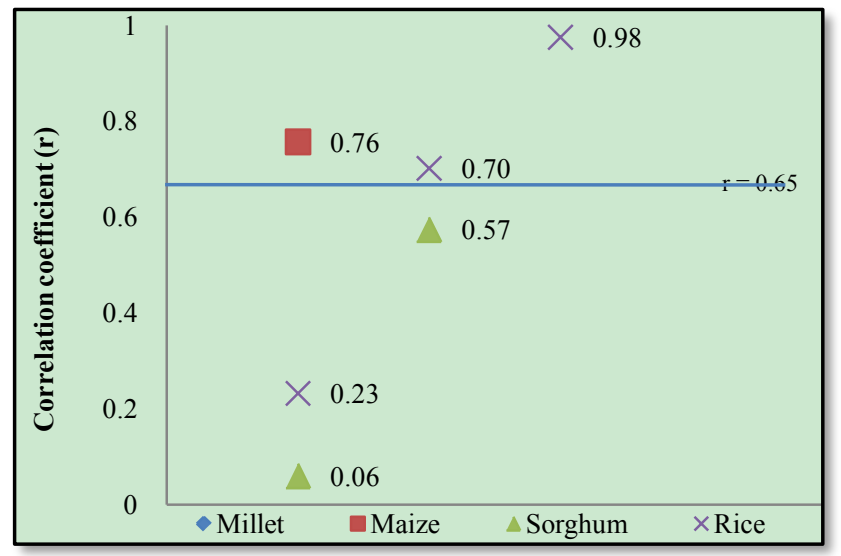

Figure 3. Correlation coefficients of Fe concentrations in cereals

Generally, an average $\mathrm{Zn}$ concentrations in cereals, Millet $(5.89 \pm 0.88 \mu \mathrm{g} / \mathrm{g})$, Maize $(3.92 \pm 0.91 \mu \mathrm{g} / \mathrm{g})$, Sorghum $(3.84 \pm$ $0.92 \mu \mathrm{g} / \mathrm{g})$, Rice $(1.80 \pm 0.32 \mu \mathrm{g} / \mathrm{g})$ was recorded in this study. ANOVA showed that with the exception of maize and sorghum, pair wise comparisons for all others revealed marked statistically significant $(\mathrm{p}<0.05)$ variations following Scheffe's post hoc test. The results further showed that samples of millet, maize and sorghum obtained from Monguno, Borno State had similar concentrations of $\mathrm{Zn}$ with mean values of $4.99 \pm 0.51 \mu \mathrm{g} / \mathrm{g}, 4.94 \pm 0.38 \mu \mathrm{g} / \mathrm{g}$ and $4.71 \pm$ $0.48 \mu \mathrm{g} / \mathrm{g}$ respectively.

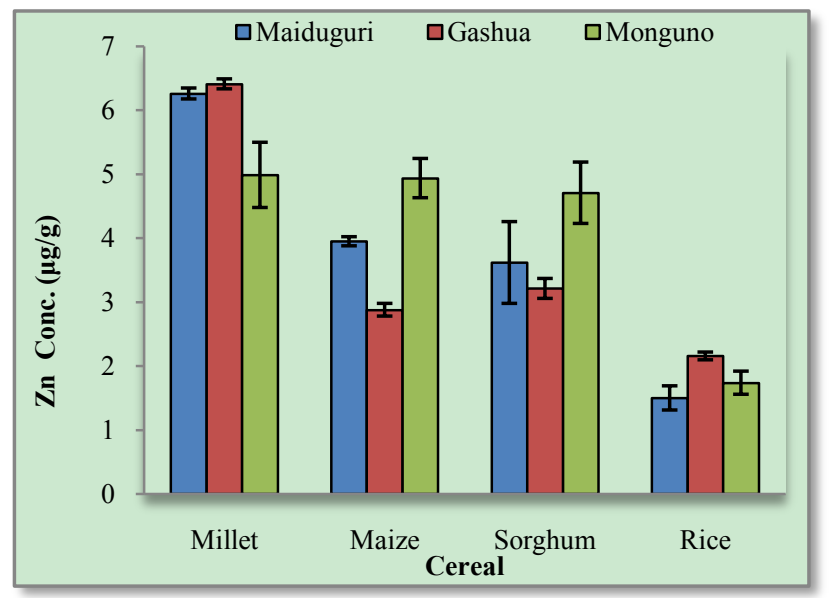

Figure 4. Zn concentrations at the different locations

Figure 5 shows the Box-Whisker plot of $\mathrm{Zn}$ concentration spread in the cereals. Non-normal (Shapiro-Wilk's test, $\mathrm{P}<0.05)$ spread was observed in Millet and Sorghum with median values $6.29 \mu \mathrm{g} / \mathrm{g}$ and $3.74 \mu \mathrm{g} / \mathrm{g}$ respectively. Figure 6 shows the Pearson correlation coefficient values for $\mathrm{Zn}$ concentrations between cereals and revealed that there was no significantly high $(\mathrm{r} \geq 0.65)$ value for $\mathrm{Zn}$ in the cereals. However, there were anti-correlations between millet and maize $(r=-0.59)$ and maize and rice $(r=-0.58)$.

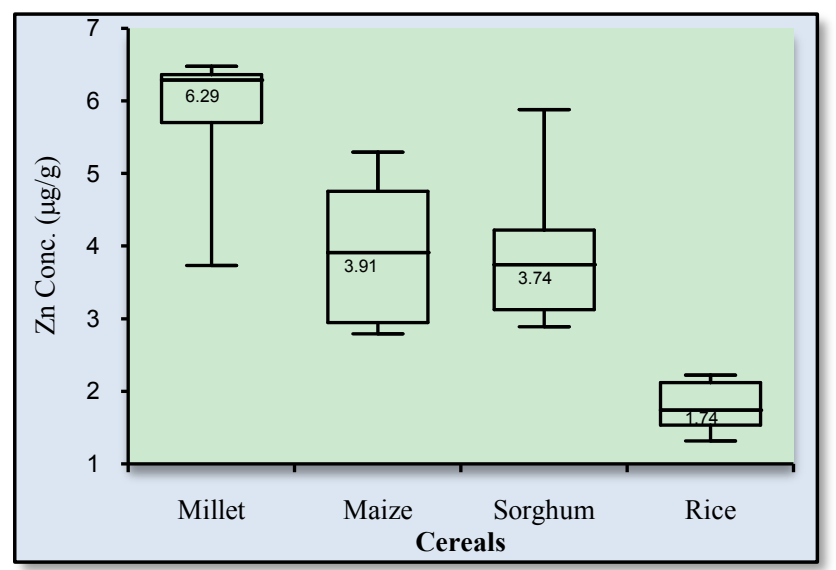

Figure 5. Box-Whisker plot of $\mathrm{Zn}$ concentration spread in cereals

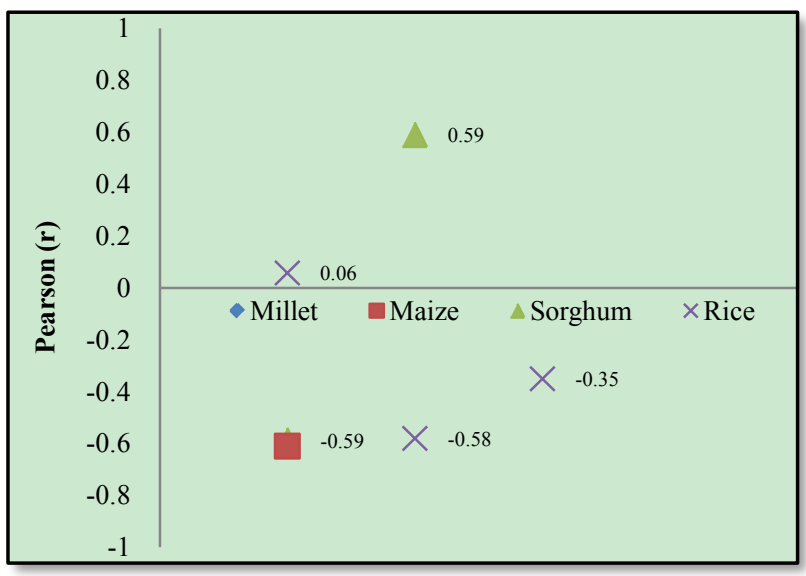

Figure 6. Correlation coefficients of $\mathrm{Zn}$ concentrations in cereals

Inter-metal correlation coefficients of $\mathrm{Fe}$ and $\mathrm{Zn}$ in each cereal sample revealed that Maize $(r=0.81)$ is highest in the association. Others are Millet $(r=0.05)$, Sorghum $(r=0.45)$ and Rice $(\mathrm{r}=0.00)$.

\section{Discussion}

The composition of $\mathrm{Fe}$ and $\mathrm{Zn}$ in the cereal grains analysed was based on wet-weight basis and the results obtained show high variability. Location especially, as well as type of cereal was found to play significant role in the variations. The levels of Fe were greatly influenced by location, while $\mathrm{Zn}$ levels were influenced by the cereal type. Fe and $\mathrm{Zn}$ contents of cereals can show wide variations[13]; differences could be considerable between mean contents of different cereals or within the same cereal species[14,15]. However, plants generally control their uptake of essential micronutrients and their translocation to the grain where there are sufficient phytoavailable amounts in the soil[16]. The grain- 
$\mathrm{Fe}$ and grain-Zn levels could vary significantly across field locations, suggesting a predominant environmental impact[17]. Thus, more than the genetic factors, the environmental conditions prevailing in the growing regions affect the mineral contents of food grains.

In this study, sorghum and millet recorded the highest mineral contents with comparable concentrations for Fe. Millet and sorghum are good sources of trace elements, and are in fact, commonly used as weaning food for babies[18], among low-income populations. However, correlation results show the trend in association of these elements and the likely combination exposure effects from $\mathrm{Fe}$ in the cereals. The combination exposure effects for $\mathrm{Fe}$ were highest in sorghum and rice. There were clearly no strong sympathetic or antipathetic relations between the $\mathrm{Zn}$ contents of the cereal grains except pronounced association in Maize and Sorghum. In an effort to identify a better nutrient variety of the staple foods, the levels of $\mathrm{Fe}$ and $\mathrm{Zn}$ were correlated in the cereal grains analysed in this study. The highest positive correlation $(\mathrm{r}=0.81)$ was found in maize, thus indicating the existence of varieties of maize that could concentrate more $\mathrm{Fe}$ and $\mathrm{Zn}$ in the grain. The maize plant in particular has a high demand for nutrients, particularly nitrogen and phosphorous for growth. Incidentally, the soil of the study area, which is nitrogen and phosphorus deficient, cannot fulfil this nutritional demand from soil-cultivation[19]. For this reason, the growing and optimal production of maize has to be supplemented with the use of nitrogen and phosphorous fertilizers, depending on the level of fertility of the soil. Generally, chemical fertilizers (NPK and Urea) which are the main sources of fertilizers for farmers[20] are very expensive and by far inadequate[21] at meeting the needs of the peasant farmers, and so farmers resort to the use of municipal waste and sewage sludge as nutrients for their crops, particularly cereals.

Rice is traditionally grown in characteristic fertile soils of varying properties of low wetlands and river valleys using irrigation fed by springs and river diversions. Applications of fertilizers are normally not necessary in the wetlands. The main rice production areas in the study area are the vertisols of New Marte and Ngala which are part of the Lake Chad Basin (a huge depression filled with quaternary deposits), the Kumadugu-Yobe wetlands of Gashua and Nguru, and the Damasak-Yau rice irrigation scheme close to the Lake Chad. Rice from these areas is milled, packed and distributed within the north-east sub-region. However, very low levels of $\mathrm{Zn}$ were found in the rice samples analysed in this study consistent with the observation that the vertisols are a localized source of zinc deficiency in the Chad Basin region of North Eastern Nigeria[22].

The $\mathrm{Fe}$ and $\mathrm{Zn}$ concentrations found in the cereal grains analysed in this study were compared with the levels reported in the literature. The $6.7 \mu \mathrm{g} / \mathrm{g}$ and $1.8 \mu \mathrm{g} / \mathrm{g}$ Fe and $\mathrm{Zn}$ levels found in the rice samples were much lower than the $25.0 \mu \mathrm{g} / \mathrm{g}$ and $18.0 \mu \mathrm{g} / \mathrm{g}$ reported for Fe and $\mathrm{Zn}$ in the unpolished rice from Taiwan[23]. Similarly rice cultivated in Tanzania was reported to contain $25.0 \mu \mathrm{g} / \mathrm{g}$ and $29.0 \mu \mathrm{g} / \mathrm{g}$ of
$\mathrm{Fe}$ and $\mathrm{Zn}$ respectively[24]. However, the Fe content recorded for the rice sample was within the range of approximate composition $(2.0-28.0 \mu \mathrm{g} / \mathrm{g})$ for milled rice reported by $\mathrm{FAO}[25]$; although the $\mathrm{Zn}$ level was less than the lower limit of the range $(6.0-25.0 \mu \mathrm{g} / \mathrm{g})$ reported by FAO for $\mathrm{Zn}$ in milled rice.

Maize grains in this study were found to contain $5.3 \mu \mathrm{g} / \mathrm{g}$ and $3.9 \mu \mathrm{g} / \mathrm{g}$ of $\mathrm{Fe}$ and $\mathrm{Zn}$ respectively. These values were very low compared to the levels of Fe $(20.0 \mu \mathrm{g} / \mathrm{g})$ and $\mathrm{Zn}$ $(10.0 \mu \mathrm{g} / \mathrm{g})$ reported for maize flour from Tanzania[24], and the $\mathrm{Fe}(29.0 \mu \mathrm{g} / \mathrm{g})$ and $\mathrm{Zn}(10.0 \mu \mathrm{g} / \mathrm{g})$ levels found for maize flour in Kenya[26]. Comparatively, the $\mathrm{Zn}$ contents of the cereal grains analysed in this study were very low; $\mathrm{Zn}$ levels were highest in millet $(5.89 \mu \mathrm{g} / \mathrm{g})$ and lowest $(1.79 \mu \mathrm{g} / \mathrm{g})$ in rice. However, such consistently lower levels of $\mathrm{Zn}$ than $\mathrm{Fe}$ in the cereal grains have been reported elsewhere within the West African sub region[27,28].

In general, cereal grains are inherently very low in concentrations of $\mathrm{Zn}$ to meet daily requirements of humans and this could be aggravated by growing cereal crops on potentially $\mathrm{Zn}$ deficient soils leading to further decreases in grain-Zn concentration[14].

On the other hand, the mean $\mathrm{Fe}$ contents recorded for sorghum, millet, maize and rice were found to be higher than the corresponding Fe levels reported by Oluyemi[29] for the same cereal grains from Ibadan in South Western Nigeria. However, the respective $\mathrm{Zn}$ levels in the same study were much higher than the concentrations reported in this study.

Furthermore, the comparable mean $\mathrm{Fe}$ concentrations found in sorghum and millet $(11.03 \mu \mathrm{g} / \mathrm{g}$ and $10.27 \mu \mathrm{g} / \mathrm{g}$ respectively) in this study were much higher than the respective levels $(3.26 \mu \mathrm{g} / \mathrm{g}$ and $0.70 \mu \mathrm{g} / \mathrm{g})[21]$ for sorghum and millet from Kano in North Western Nigeria. Similarly, the mean $\mathrm{Zn}$ levels for sorghum and millet reported in the same study were lower than the mean $\mathrm{Zn}$ concentrations found in this study for sorghum and millet respectively. The low cereal mineral levels reported around Kano might be associated with the phosphorus and zinc deficiencies observed in some partially irrigated schemes in Kano[22].

Therefore, any contrast on the nutritional quality of the cereal grains analysed in this study could be attributed to differences of local soil conditions of the regions of cultivation and genetic variability of the seed genotypes. Direct relationship between low soil zinc levels and the occurrence of deficiency zinc contents of crops (rice), and human zinc deficiency were observed in Bangladesh[30], and in India[31], in which cereals are a major source of daily caloric intakes. As an alternative to food fortification, the micronutrient content of cereal grains could be improved through plant breeding or selection of appropriate plant strains. In the Philippines, a rice variety with $400-500 \%$ higher Fe content than common varieties was developed[32] for farmers to use on micronutrient-poor soils and improve nutritional quality simultaneously.

More importantly, as with all cereals, most nutrients are concentrated in the outer layer of the grain; thus removing these layers in the milling process might result in the greater 
loss of minerals. Bauernfeind[33] reported a loss of $79 \%$ of $\mathrm{Zn}, 54 \%$ of $\mathrm{Fe}$ and $53 \%$ of $\mathrm{Ca}$ when a maize grain was milled and Maina[26] reported a 70\% loss of $\mathrm{Zn}, 34 \% \mathrm{Fe}$ and $13 \% \mathrm{Ca}$. Polishing and washing rice (i.e. polished and parboiled rice grain) could affect the Fe and $\mathrm{Zn}$ levels in the edible product[23]. In Nigeria, it is common practice to wash rice before cooking thus further reducing the amounts of essential minerals available for intake from the diet.

Considering the nutritional value of food is on the basis of its essential trace contents, then millet and sorghum grown in the North Eastern Nigeria could be said to be more nutritious than rice and maize from the same area. However, the nutritional value of any diet depends also on the bioavailability of the elements within the food, i.e. the extent to which the essential elements in the diets are absorbed from the gastrointestinal tract and reaches the blood. The absence of dehulling, sieving and soaking have resulted in high amounts of phytic acid in some sorghum-based local dishes[28]. The bioavailability of $\mathrm{Fe}$ and $\mathrm{Zn}$ in cereals is affected by the presence of phytic acid and polyphenols in the grains [34-36]. The hull is rich in phytic acid which binds $\mathrm{Fe}$ and $\mathrm{Zn}$ and makes them biologically unavailable[37]. High concentration of phytic acid implies low absorption of $\mathrm{Fe}$ and $\mathrm{Zn}$ in the gastrointestinal tract, and this could lead to trace element malnutrition especially when cereals are used as weaning foods for children.

On the other hand, the absorption of Fe and $\mathrm{Zn}$ could be boosted if a meal is taken with a portion of animal protein because these proteins prevent the elements from forming insoluble phytates with the phytic acid in the foods. However, food items rich in haem-Fe (meat, fish) are expensive and vitamin-C-rich vegetables and fruits (enhancers) are only available during a short period of the year. These constraints make it difficult to increase intake of micronutrients from poor quality diets.

Similarly, tea which is commonly used as a drink with meals has high concentration of tannin, which may pose a problem, because tannin is another anti-nutrient compound which hinders the absorption of Fe. Thus, this dietary habit of the people invariably would reduce the absorption of nutritionally essential elements such as $\mathrm{Fe}$ and $\mathrm{Zn}$ from the staple foods. Therefore, means to enhance the absorption of these elements in staple foods have to be initiated. The traditional methods of soaking, fermentation and germination of grains and flours before cooking reported to reduce phytic acid considerably from cereal meal could be used at local rural households to improve the bioavailability of $\mathrm{Fe}$ and $\mathrm{Zn}$ from the diet. These methods are simple, cheap and effective but are not routinely practised in this region. A malnourished body more often than not absorbs more toxic elements than a well nourished one. For instance, low dietary intake of $\mathrm{Fe}$, selenium (Se) and calcium (Ca) may lead to more absorption of lead $(\mathrm{Pb})$ and cadmium $(\mathrm{Cd})$ in the gastrointestinal tract[38]. $\mathrm{Pb}$ and $\mathrm{Cd}$ in the body are toxic as $\mathrm{Pb}$ interferes with physical and intellectual development of children and with utilisation of essential nutrients such as $\mathrm{Fe}$ and vitamin $\mathrm{A}[39]$.
Malnutrition is not always a result of not having enough food to eat but often times it is on how to turn the available foods into safe and nutritious meals.

\section{Conclusions}

This study revealed low levels of $\mathrm{Zn}$ and Fe in the cereal grains from the study area and this observation might be a risk factor for micronutrient malnutrition in the populations depending so much on such diets.

It can be concluded that combining cereal grains in meals such as rice and sorghum are likely to improve on $\mathrm{Fe}$ intake.

\section{ACKNOWLEDGEMENTS}

Authors wish to acknowledge the support of the Zonal Laboratory of National Agency for Food Drug Administration and Control (NAFDAC), for assisting in the elemental analysis.

\section{REFERENCES}

[1] WHO: World Health Organisation (2005). World Health Report: Make every mother and child count World Health Organization, Geneva

[2] UNICEF: United Nations International Children Education Fund (2007). The State of the world's children 2007 UNICEF, New York

[3] WHO: World Health Organisation (2001). Iron deficiency anaemia: Assessment prevention and control, WHO Geneva

[4] WHO (2004). Iron supplementation of young children in regions where malaria transmission is intense and infectious diseases highly prevalent World Health Organisation, Geneva

[5] Stoltzfus, R. J., Chwaya, H. M., Tielsch, J. M., Schulze, K. J., Albonico, M. and Savioli, L. (1997). Epidemiology of iron deficiency anaemia in Zanzibari schoolchildren: the importance of hookworms, American Journal of Clinical Nutrition $65,153-159$

[6] Lwambo, S N. J. Brooker, S. Siza, J. E. Bundy, D. A. P. and Guyatt, H. (2000). Age patterns in stunting European, Journal of Clinical Nutrition 54, 36-40

[7] Horton, S. and Levin, C. (2001). Commentary on "Evidence that iron deficiency anaemia causes reduced work capacity", Journal of Nutrition 131, 691S-696S

[8] Gordon, N. (2003). Iron deficiency and the intellect, Brain \& Development 25, 3-8

[9] Salama AK, Radwan, MA. (2005). Heavy metals (Cd, Pb) and trace elements $(\mathrm{Cu}, \mathrm{Zn})$ contents in some foodstuffs from the Egyptian market, Emir. J. Agric. Sci.; 17 (1): 34-42

[10] Vogel AI. (2000). Vogel's Textbook of Quantitative Chemical Analysis 6th Ed. Revised by Mendham, J., Denney, R. C., 
Barnes, J. D. and Thomas, M. J. K. Pearson Edu. Ltd. India. p. 104-107; 602-607

[11] SC: Shimadzu Corporation (2000). Atomic Absorption Spectrometry Cookbook: Water Analysis, Analytical Instruments Division, Kyoto Japan, G10 (1-32)

[12] Rowe P. (2007). Essential Statistics for the Pharmaceutical Sciences. John Wiley \& Sons, England. p. 127.

[13] Meng, F. Wei, Y. and Yang, X. (2005). Iron content and bioavailability in rice, J. Trace Elements in Medicine and Biology 18, 333-338

[14] Cakmak, I. (2002). Plant nutrition research: Priorities to meet human needs for food in sustainable ways, Plant and Soil 247, 3-24.

[15] Kennedy, G. and Burlinghame, B. (2003). Analysis of food composition data on rice from a plant genetic resources perspective, Food Chemistry 80, 589-596

[16] Welch, R.M. (1995). Micronutrient nutrition of plants, Critical Reviews of Plant Science 14, 49-82

[17] Kayode, A. P. P., Linnemann, A. R., Hounhouigan, J. D., Nout, J. R. and van Boekel, M.A.J.S. (2006). Genetic and Environmental Impact on Iron, Zinc and Phytate in Food

[18] Asubiojo, O. I. Nkono, N. A. Ogunsua, A. O. Oluwole, A. F. Ward, N. I. Akanle, O. A.; Spyrou, N. M. (1997). Trace elements in drinking and groundwater samples in southern Nigeria, The Science of the Total Environment 208, 1-8

[19] Rayar, A.J. (1987). Studies on some physico-chemical parameters of soils of Borno state, Annals of Borno University of Maiduguri, 4, 283-291

[20] Abubakar, S. Z., Suleiman, M. A. and Murtala, G. B. (2004). Targeted Bench- Mark Survey Report on Farmers Practices for Special food Production for a Kano State, Agricultural and Rural Development Authority, KNARDA 37- 41

[21] Tudunwada, I. Y. Essiet, E.U. and Mohammed, S.G. (2007). The effects of Tannery sludge on heavy metals concentration in cereals on small-holder farms in Kano, Nigeria Not Bot Hort Cluj 35(2), 55- 60

[22] Kebbeh, M. Haefele, S. and Fagade, S. O. (2003). The Nigerian Rice Economy in a Competitive World: Constraints, Opportunities And Strategic Choices Challenges and Opportunities for Improving Irrigated Rice Productivity in Nigeria, West Africa Rice Development Association (WARDA) Abidjan, Cote d'Ivoire

[23] Yeh, S. J., Chen, P. Y., Ke, C. N., Hsu, S. T. and Tanaka, S. (1976). Residue Analyses of the Official Testing of Pesticides Analytica Chimica Acta 87, 119-124

[24] Mohammed, N.K. (2008). Nuclear Techniques Applied to Biological Samples from Tanzania to Monitor the Nutritional Status of Children. PhD Thesis Faculty of Engineering and Physical Sciences University of Surrey, United kingdom

[25] FAO: Food and Agriculture Organization (1993). Rice in Human Nutrition FAO and IRRI, Rome, Italy

[26] Maina, D. (2005). Pesticide and Poverty A case study on trade and utilization of pesticides in Tanzania IAEA XRF Newsletter 10-11

[27] Adeyeye, E. I. Arogoundade, L. A. Akintayo, E. T. Aisida, O. A. and Alao, P. A. (2000). Calcium, zinc and phytate interrelationships in some foods of major consumption in Nigeria, Food Chemistry 71, 435-441

[28] Mitchikpe C. E. S. (2007). Towards a food-based approach to improve iron and zinc status of rural Beninese children: enhancing mineral bioavailability from sorghum-based food. PhD Thesis Wageningen University, Netherlands

[29] Oluyemi, E.A. Akinlua, A.A. Adenuga, A.A. and Odebajo, M.B. (2005) mineral contents of some commonly consumed Nigerian foods European Journal of Scientific Research 6 (2), 11-15

[30] Mayer, A. Latham, M.B. Duxbury, M.C. Frongillo, J.M. Hassan, E.A. and Biswas, T. (2003). The zinc content of rice in Bangladesh: relationship to soil, production methods, diets and the zinc status of children, FASEB Journal 17, A1200-1200 Part 2 Suppl

[31] Gupta, R.C. (2006). Toxicology of organophosphate and carbamate compounds, Elsevier Academic Press, Amsterdam 763

[32] Haas, J. D. Beard, J. L. Murray-Kolb, L. E. del Mundo, A. M. Felix, A. Gregorio, G. B. (2005). Iron-bio fortified rice improves the iron stores of nonanemic Filipino women, Journal of Nutrition 135, 2823-2830

[33] Bauernfeind, J. C. Ed, (1991). Cereal Grain Products: In Nutrient Addition to Foods, Food and Nutrition Press, Trumbull, CT, 23-44

[34] Brune, M. Rossander-Hulten, L. Hallberg, L. and Gleerup, A. Sandberg, A.S. (1992). Iron absorption from bread in humans: Inhibiting effects of cereal fibre, phytate and inositol phosphates with different numbers of phosphate groups, J Nutr $122,442-449$

[35] Sandberg, A. S., Brune, M. Carlsson, N. G., Hallberg, L., Skoglund, E. and Rossander-Hulthen, L. (1999). Inositol phosphates with different numbers of phosphate groups influence iron absorption in humans American Journal of Clinical Nutrition 70, 240-246.

[36] Towo, E. Matuschek, E. and Svanberg, U. (2006). Fermentation and enzyme treatment of tannin sorghum gruels: Effects of phenolic compounds, phytate and in vitro accessible iron, Food Chemistry 94, 369-376.

[37] Adams, C. L. Hambidge, M. Raboy, V. Dorsch, J. A. Sian, L. Westcott and J. L. Krebs, N. F (2002). Zinc absorption from a low-phytic acid maize, American Journal of Clinical Nutrition 76, 556-559.

[38] Osman, K. Schutz, A. Akesson, B. Maciag, A. and Vahter, M. (1998). Interactions between essential and toxic elements in lead exposed children in Katowice, Poland Clinical Biochemistry $31,657-665$

[39] Ahamed, M. Verma, S. Kumar, A. and Siddiqui, M. K. J. (2005). Exposure to lead and its correlation with biochemical indices in children, Science of the Total Environment 346, $48-55$ 